\title{
WĄTPLIWOŚCI WOKÓL KONSTYTUCYJNOŚCI SANKCJI KARNYCH I ADMINISTRACYJNO-KARNYCH ZA NARUSZENIE PRZEPISÓW O OCHRONIE DANYCH OSOBOWYCH
}

Przepisy zarówno ogólnego rozporządzenia o ochronie danych osobowych (RODO), jak i ustawy o ochronie danych osobowych w zakresie, w jakim normują sankcje karne i administracyjno-karne, nie tylko wywołują liczne wątpliwości natury konstytucjonalno-prawnej, ale wręcz naruszają niektóre gwarancje ustanowione w Konstytucji RP, a także w Karcie Praw Podstawowych Unii Europejskiej. Nie można utożsamiać naruszenia przepisów o ochronie danych osobowych z naruszeniem interesu publicznego, a także aprobować stosowania sankcji karnych i administracyjno-karnych oraz ich wymiaru w oderwaniu od faktu i stopnia naruszenia interesu publicznego. Uwaga prawodawcy powinna koncentrować się nie na sankcjonowaniu każdego naruszenia przepisów o ochronie danych osobowych, a raczej na skutecznym przeciwdziałaniu i zwalczaniu za pomocą wymienionych kar oraz innych środków najbardziej niebezpiecznych praktyk związanych z przetwarzaniem danych osobowych. W okresie dynamicznego rozwoju nowoczesnych technologii i wywierania przez nie coraz większego wpływu na faktyczną realizację konstytucyjnych praw i wolności oraz praw podstawowych władza publiczna w znacznie większym stopniu niż dotychczas powinna zadbać o bezpieczeństwo obrotu.

Słowa kluczowe: konstytucyjność sankcji karnych i administracyjno-karnych za naruszenie przepisów o ochronie danych osobowych, zasada proporcjonalności i równego traktowania wobec prawa, RODO, ustawa o ochronie danych osobowych, Konstytucja RP, Karta praw podstawowych Unii Europejskiej; relacje prawa krajowego i unijnego oraz rozwiązywanie kolizji między tymi systemami normatywnymi w kontekście ochrony danych osobowych

\section{DOUBTS CONCERNING THE CONSTITUTIONALITY OF CRIMINAL SANCTIONS AND ADMINISTRATIVE FINES FOR VIOLATING PROVISIONS ON THE PERSONAL DATA PROTECTION}

The provisions of both the General Data Protection Regulation (GDPR) and the Personal Data Protection Act (UODO) to the extent that they regulate criminal and administrative penalties not only create numerous constitutional and legal doubts, but also violate some of the guarantees established in the Constitution of the Republic of Poland, as well as in the Charter of Fundamental Rights of the European Union. It is not possible to equate the violation of personal data protection provisions and the violation of public interest, and to approve the application of criminal and administrative sanctions and their dimension in isolation from the fact and the degree of public interest violation. The attention of the legislator should focus not so much on sanctioning any violation of the provisions on the protection of personal data, but rather on effective counteracting and combating, by means of the aforementioned penalties and other measures, the most dangerous practices related to the processing of personal data. In the era of dynamic development of modern technologies and exerting an ever-increasing influence on the actual realization of constitutional rights and freedoms and fundamental rights, public authorities should show concern for the conduct of legal transactions to a much greater extent than before. 
Key words: constitutionality of criminal sanctions and administrative fines for the violation of provisions on the personal data protection, principle of proportionality and equal treatment under the law, GDPR, Personal Data Protection Act, Constitution of the Republic of Poland, EU Charter of Fundamental Rights, relations between national law and EU law and resolving conflicts between these normative systems in the context of personal data protection

*Dr hab. Bogusław Soltys, Uniwersytet Wrocławski, boguslaw.soltys@uwr.edu.pl, https://orcid.org/0000-0002-8359-7732

\section{WSTĘP}

Clem autora artykułu było przedstawienie różnych wątpliwości i wyrażenie zastrzeżeń w zakresie zgodności $\mathrm{z}$ Konstytucją $\mathrm{RP}^{1}$ regulacji sankcji karnych i karno-administracyjnych za naruszenie przepisów o ochronie danych osobowych. Sankcje te zostały unormowane w rozporządzeniu Parlamentu Europejskiego i Rady Unii Europejskiej nr 2016/679 [dalej: RODO] ${ }^{2}$ oraz w ustawie z dnia 10 maja 2018 r. o ochronie danych osobowych [dalej: u.o.d.o.] ${ }^{3}$. Według art. 107 u.o.d.o., kto przetwarza dane osobowe, choć ich przetwarzanie nie jest dopuszczalne albo do ich przetwarzania nie jest uprawniony, podlega grzywnie, karze ograniczenia wolności albo pozbawienia wolności do lat dwóch. Jeśli taki czyn dotyczy danych ujawniających pochodzenie rasowe, poglądy polityczne, przekonania religijne lub światopoglądowe, przynależność do związków zawodowych, danych genetycznych, danych biometrycznych przetwarzanych w celu jednoznacznego zidentyfikowania osoby fizycznej, danych odnoszących się do zdrowia, seksualności lub orientacji seksualnej podlega grzywnie, karze ograniczenia wolności albo pozbawienia wolności do lat trzech. Na podstawie art. 108 u.o.d.o. odpowiedzialności karnej sankcjonowanej grzywną, karą ograniczenia wolności albo pozbawienia wolności do lat dwóch podlega również ten, kto udaremnia lub utrudnia prowadzenie kontroli przestrzegania przepisów o ochronie danych osobowych, a także ten, kto w związku z toczącym się postępowaniem w sprawie nałożenia administracyjnej kary pieniężnej nie dostarcza danych niezbędnych do określenia podstawy wymiaru kary pieniężnej lub dostarcza dane, które uniemożliwiają ustalenie podstawy wymiaru kary pieniężnej. Zgodnie natomiast z art. 83 ust. 4-6 RODO właściwe organy za poszczególne bardzo szeroko ujęte naruszenia przepisów mogą nakładać kary pieniężne w wysokości odpowiednio do $10 \mathrm{mln}$ euro lub do $20 \mathrm{mln}$ euro, w przypadku przedsiębiorstwa do $2 \%$ lub do $4 \%$ jego całkowitego rocznego światowego obrotu z poprzedniego roku obrotowego (w każdym przypadku do kwoty wyższej w razie

${ }^{1}$ Konstytucja RP z dnia 2 kwietnia 1997 r. (Dz.U. z 1997 r. nr 78, poz. 483).

${ }^{2}$ Rozporządzenie Parlamentu Europejskiego i Rady Unii Europejskiej nr 2016/679 z dnia 27 kwietnia 2016 r. w sprawie ochrony osób fizycznych w związku z przetwarzaniem danych osobowych i w sprawie swobodnego przepływu takich danych oraz uchylenia dyrektywy 95/46/WE, tzw. ogólne rozporządzenie o ochronie danych osobowych (Dz.U. UE L 2016.119.1 z 4.05.2016).

${ }^{3}$ Ustawa z dnia 10 maja 2018 r. o ochronie danych osobowych (Dz.U. z 2018 r. poz. 1000). 
obrotu mniejszego od tych kwot), natomiast za nieprzestrzeganie już orzeczonych nakazów administracyjnych kary w wysokości wskazanych wcześniej ich maksymalnych pułapów.

Duża dotkliwość sankcji, a przede wszystkim nieokreśloność i rozproszenie ich uregulowania ${ }^{4}$ rodzi szereg pytań dotyczących relacji ochrony danych osobowych oraz ochrony innych konstytucyjnie gwarantowanych praw i wolności, a także dopuszczalności i zakresu ich reglamentacji. Mają one znaczenie zarówno w kontekście wykładni obowiązujących przepisów, jak i oceny ich zgodności z konstytucją. Zastrzeżenia odnośnie do konstytucyjności regulacji sankcji karnych i administracyjno-karnych za naruszenie przepisów o ochronie danych osobowych nie były dotychczas przedmiotem analizy przedstawicieli doktryny prawa oraz osądu Trybunału Konstytucyjnego. Podjęcie tego tematu, zwłaszcza po wprowadzeniu w życie RODO, wydaje się zatem uzasadnione i ważne - zarówno w odniesieniu do nauki prawa, jak i praktyki jego stosowania.

\section{WPROWADZENIE DO PROBLEMATYKI}

W ostatnim czasie zarówno w prawodawstwie krajowym, jak i europejskim doszło do istotnego zwiększenia ochrony danych osobowych, choć do niedawna jeszcze koncentrowała się ona nie tyle na poszczególnych danych umożliwiających identyfikację osoby fizycznej, lecz na sferze prywatności człowieka. Można odnieść wrażenie, że nastąpiło swoiste rozczłonkowanie ogólnego dobra prywatności na szereg odrębnych dóbr, podobnie jak ponad 100 lat wcześniej w odniesieniu do ogólnego dobra osobistości, z którego z czasem wyszczególniono sferę prywatności człowieka oraz jego inne dobra o charakterze osobistym ${ }^{5}$. Konstruowanie wokół tych dóbr coraz większej liczby jednostkowych praw podmiotowych sui generis przeważnie postrzegane jest jako zjawisko pozytywne, sugerujące wysoki poziom zaspokojenia obiektywnych potrzeb człowieka oraz jego ochrony przed różnymi zagrożeniami współczesnego świata. Aktualnie duży impuls do takiego zapatrywania daje dynamicznie rozwijająca się gospodarka w wymiarze globalnym, powszechna informatyzacja, automatyzacja oraz rozwój sztucznej inteligencji. Jednocześnie nie można jednak nie dostrzegać, że tworzenie nadmiernej liczby praw nieuchronnie prowadzi do ich inflacji, co ostatecznie obraca się zwykle przeciwko człowiekowi oraz jego przyrodzonej i niezbywalnej godności będącej w naszym porządku prawnym źródłem wszelkich prawnie chronionych praw i wolności. Zgodnie z art. 30-32 konstytucji godność ludzka — oprócz tego, że jest naturalnym źródłem innych praw i wolności — sama jest nienaruszalna, a jej poszanowanie jest obowiązkiem władz publicznych. Każdy jest obowiązany szanować

${ }^{4}$ Warto podkreślić, że w przypadku odpowiedzialności karnej za naruszenie niektórych przepisów o ochronie danych osobowych hipotezy i sankcje norm sankcjonujących zostały przewidziane w ustawie, natomiast ich dyspozycje w rozporządzeniu unijnym.

${ }^{5}$ Do utrwalenia i rozpowszechnienia koncepcji ogólnego dobra osobistego w największym stopniu przyczynił się O.F. von Gierke i J. Kohler, a w polskiej doktrynie F. Zoll i S. Grzybowski. Vide więcej na ten temat M. Lijowska, Koncepcja ogólnego prawa osobistości w niemieckim i polskim prawie cywilnym, „Kwartalnik Prawa Prywatnego” 2001, z. 4, s. 718 i n. 
wolności i prawa innych osób, nikogo nie można zmuszać do czynienia tego, czego prawo mu nie nakazuje, natomiast ograniczenia wolności i praw mogą być wprowadzane tylko wyjątkowo w formie ustawy, jeśli są one konieczne do realizacji określonego interesu publicznego lub wolności i praw innych osób, przy czym wszyscy są równi wobec prawa i mają prawo do równego traktowania przez władze publiczne.

W prawodawstwie można zaobserwować pewną prawidłowość, a mianowicie im więcej tworzy się różnych praw i wolności, tym większy zakres reglamentacji staje się niezbędny dla zapewnienia możliwości korzystania z nich, zwłaszcza przy zachowaniu pewnych standardów uznawanych za wyznacznik demokratycznego państwa prawa. W kontekście prowadzonych rozważań na szczególne podkreślenie zasługuje sformułowana w art. 30 konstytucji gwarancja nienaruszalności godności osoby ludzkiej oraz przewidziana $\mathrm{w}$ art. 31 ust. 3 gwarancja nienaruszalności istoty poszczególnych praw i wolności. Nie można bowiem tworzyć takich ograniczeń praw i wolności, które ingerują w ich rdzeń, konstruujący oraz wyznaczający sens danego prawa lub wolności. Rozczłonkowanie poszczególnych praw i wolności na samodzielne prawa podmiotowe i zakaz naruszenia ich istoty prędzej czy później obiektywnie prowadzi do częściowej, a niekiedy nawet całkowitej niemożliwości wykonania, w efekcie czego konstytucyjne gwarancje ochrony zostają bez pokrycia. Przy wykładni przepisów o ochronie danych osobowych trzeba mieć więc na względzie, że nie tylko godność człowieka jest nienaruszalna, ale również istota $\left(\right.$ natura $\left.^{6}\right)$ każdego konstytucyjnie gwarantowanego prawa lub wolności nie może być w żaden sposób reglamentowana, choćby przez wprowadzanie do obowiązującego porządku prawnego bezpośrednich lub pośrednich zakazów, tworzenie innych praw i wolności czy też powszechne akceptowanie określonego sposobu ich wykonywania.

W orzecznictwie Trybunału Konstytucyjnego wyraźnie zaznaczono, że ograniczeń istoty konstytucyjnych praw i wolności nie mogą uzasadniać żadne ważne względy, nawet bezpośrednie odwoływanie się do przepisów konstytucji, naruszenie zaś ich rdzenia może wynikać także z rozmiaru różnych pojedynczych form reglamentacji, które - mimo że same $\mathrm{z}$ osobna nie stanowią niedozwolonej ingerencji - w sumie mogą doprowadzić do przekształcenia określonego prawa lub wolności w ich pozór? Przy czym nie chodzi jedynie o formalną redukcję treści danego prawa lub wolności do jednostkowej alternatywy możliwości wyboru określonego zachowania się podmiotów uprawnionych, ale przede wszystkim o ich wymiar materialny, który może tkwić zarówno w całokształcie uprawnień składających się na chronioną sferą możliwości postępowania, jak i dotyczyć tylko niektórych z nich, jeśli w strukturze danego prawa lub

${ }^{6}$ Wyznacza ona bowiem nienaruszalny rdzeń danego prawa lub wolności wyrażający sens ich istnienia. Nie tylko jednak prawodawca nie może ingerować w tak rozumiany rdzeń, ale również podmioty korzystające z określonych praw i wolności nie mogą naruszać ich natury; confer np. art. $353^{1}$ ustawy z dnia 23 kwietnia 1964 r. Kodeks cywilny (tekst jedn. Dz.U. z 2018 r. poz. 1025, ze zm.) [dalej k.c.].

7 Zamiast wielu vide np.: wyrok TK z 10 października 2000 r., sygn. akt. P 8/99, OTK ZU 2000/6/190; wyrok TK z 12 stycznia 2000 r., sygn. akt P 11/98, OTK ZU 2000/1/3; wyrok TK z 17 maja 2006 r., sygn. akt K 33/05, OTK ZU 2006/5A/57; wyrok TK z 7 listopada 2006 r, sygn. akt SK 42/05, OTK ZU 2006/10A/148. 
wolności mają podstawowe znaczenie. Konstytucja RP chroni bowiem prawa i wolności w obu ich aspektach: formalnym i materialnym ${ }^{8}$. Przy tak rozumianych gwarancjach nadmierna ochrona jednych praw lub wolności może zatem doprowadzić do wypaczenia sensu innych, co zgodnie z Konstytucją RP jest niedozwolone i nie powinno być aprobowane ani w procesie legislacyjnym, ani w praktyce stosowania obowiązujących przepisów. We wszystkich przypadkach, w których przepisy konstytucji bezpośrednio lub pośrednio nie rozstrzygają o pierwszeństwie hierarchiczno-zakresowym określonych praw lub wolności względem siebie, przy zachowaniu gwarancji ustrojowych należy dążyć do w miarę pełnego urzeczywistnienia wszystkich konstytucyjnie gwarantowanych praw i wolności.

\section{KONSTYTUCYJNE PODSTAWY OCHRONY DÓBR ZWIĄZANYCH Z DANYMI OSOBOWYMI}

Po tych niezbędnych uwagach wprowadzających wypada odnotować, że według konstytucji każdy ma prawo do ochrony prawnej życia prywatnego (art. 47). Nikt nie może być zobowiązany inaczej niż na podstawie ustawy do ujawnienia informacji dotyczących jego osoby (art. 51 ust. 1). Władze publiczne nie mogą pozyskiwać, gromadzić i udostępniać informacji o obywatelach innych niż niezbędne w demokratycznym państwie prawnym (art. 51 ust. 2). Każdy ma prawo dostępu do dotyczących go urzędowych dokumentów i zbiorów danych, a ograniczenia tego prawa mogą być określone jedynie w formie ustawy (art. 51 ust. 3). W stosunku natomiast do wszelkich danych - niezależnie przez kogo są one gromadzone — każdy ma prawo do żądania ich sprostowania oraz usunięcia informacji nieprawdziwych, niepełnych lub zebranych w sposób sprzeczny z ustawą (art. 51 ust. 4). Zasady i tryb gromadzenia oraz udostępnienia informacji powinna określać ustawa (art. 51 ust. 5). Władze publiczne chronią konsumentów przed działaniami zagrażającymi ich prywatności i bezpieczeństwu na zasadach określonych w ustawie, przy czym prawa tego można dochodzić tylko w granicach wyznaczonych w ustawie (art. 76 w zw. z art. 81).

Konstytucja RP jednak zapewnia także wolność i ochronę tajemnicy komunikowania się, których ograniczenie może nastąpić jedynie w przypadkach określonych w ustawie i tylko w unormowany w niej sposób (art. 49), gwarantuje wolność pozyskiwania i rozpowszechniania informacji (art. 54 ust. 1), a także inne prawa i wolności, które w większym lub mniejszym stopniu zachodzą na siebie zakresowo. W rezultacie przynajmniej część z konstytucyjnie określonych praw i wolności może pozostawać ze sobą w kolizji uniemożliwiającej ich pełną realizację. Przykładowo nie jest możliwe całkowicie swobodne komunikowanie się oraz pozyskiwanie i rozpowszechnianie informacji bez ingerencji w prawo do ochrony życia prywatnego czy różnych aspektów ochrony danych osobowych.

Warte podkreślenia jest, że w konstytucji nie ustanowiono osobnego prawa do ochrony danych osobowych jako takich, lecz zagwarantowano ochronę tylko niektórych

\footnotetext{
${ }^{8}$ Vide wyroki TK powołane w przyp. 7.
} 
jego jednostkowych elementów. W tym zakresie unormowania konstytucji przynajmniej werbalnie różnią się od postanowień Karty praw podstawowych Unii Europejskiej [dalej: KPP] ${ }^{9}$ zapewniających każdemu generalne prawo do ochrony danych osobowych, które go dotyczą (art. 8 ust. 1). Poza odrębnością niektórych zagadnień szczegółowych wspólną cechą obu regulacji w kwestii zasad przetwarzania danych osobowych jest jednak odesłanie do unormowań ustawowych (por. art. 51 ust. 5 konstytucji i art. 8 ust. $2 \mathrm{KPP}$ ). Natomiast jeśli chodzi o wolność komunikowania się oraz pozyskiwania i rozpowszechniania informacji to - podobnie jak w odniesieniu do prawa (poszanowania) prywatności - zarówno w konstytucji, jak i w KPP zapewniono ochronę tych wolności i praw bez delegowania do ich bliższego określenia w aktach prawnych niższego rzędu (por. art. 47, 49 i 54 ust. 1 konstytucji oraz art. 7 i 11 KPP). Oczywiście rozwiązanie to nie oznacza zakazu szczegółowego regulowania praw i wolności wyrażonych w konstytucji ${ }^{10}$, w końcu zgodnie $\mathrm{z}$ art. 31 ust. 3 konstytucji każde prawo lub wolność do pewnego stopnia można ustawowo ograniczyć, niemniej jednak może ono wskazywać na odpowiednio wyższą rangę chronionego dobra.

Znaczenia nabiera zatem ustalenie relacji zachodzących między prawem do ochrony danych osobowych a innymi podstawowymi i konstytucyjnymi prawami podmiotowymi, szczególnie w kontekście sankcji stanowiących gwarancję ich realizacji. Służąc ochronie poszczególnych praw, mogą one bowiem wywierać znaczący wpływ na zachodzące między nimi relacje, nie zawsze adekwatnie do rangi danego prawa czy proporcjonalnie względem innych praw. Biorąc pod uwagę rozległość oraz bardzo dużą dotkliwość sankcji za naruszenie przepisów o ochronie danych osobowych, można odnieść mylne wrażenie, że dane osobowe są dobrami hierarchicznie ważniejszymi względem większości innych praw i wolności, np. wolności komunikowania się, wolności słowa czy pozyskiwania i rozpowszechniania informacji. W kontekście samego zagrożenia administracyjnymi karami pieniężnymi można nawet stwierdzić, że w systemie polskiego prawa dane osobowe są obecnie najbardziej chronionymi dobrami, zaraz po konkurencji ${ }^{11}$.

\section{WZAJEMNE RELACJE CHRONIONYCH DÓBR}

W przepisach o ochronie danych osobowych zasadniczo nie uregulowano ich relacji do innych aktów prawnych ${ }^{12}$, w motywach preambuły RODO wyraźnie jednak

${ }^{9}$ Karta praw podstawowych Unii Europejskiej (Dz.U. UE. C 2007.303.1 z 14.12.2007).

${ }^{10}$ Należy dodać, że nie przekreślono również możliwości uznawania za konstytucyjne prawo podmiotowe tych unormowań konstytucji, które mimo odesłania do regulacji ustawowych dostatecznie wyrażają jakieś prawo lub wolność. Stanowisko to na ogół jest akceptowane w literaturze; vide np. P. Tuleja, Stosowanie Konstytucji RP w świetle zasady jej nadrzędności (wybrane problemy), Kraków 2003, s. 142 i n.

${ }^{11}$ Nawet życie człowieka oraz jego integralność nie otrzymały takiego wsparcia prawodawcy. Confer także art. 83 ust. 4-6 RODO z art. 106 ust. 1 i 2 ustawy z dnia 16 lutego 2007 r. o ochronie konkurencji i konsumentów (Dz.U. z 2018 r. poz. 798; dalej: u.o.k.k.).

${ }^{12}$ Confer art. 23 RODO. Należy zaznaczyć, że przepis ten w żadnym razie nie obliguje do zmiany przepisów konstytucyjnych w celu zapewnienia pełnego stosowania RODO, lecz konstytuuje przesłanki dopuszczalności wprowadzenia nowych unormowań niższej rangi ograniczających standardy ochrony danych osobowych na podobnych zasadach, jakie zostały przewidziane w art. 31 ust. 3 konstytucji. Vide więcej na ten 
wskazano, że prawo do ochrony danych osobowych nie jest prawem bezwzględnym, lecz należy je postrzegać w kontekście jego funkcji społecznej i wyważyć względem innych praw podstawowych zgodnie z zasadą proporcjonalności. RODO nie narusza praw podstawowych, wolności i zasad uznanych w KPP i zapisanych w traktatach, w szczególności prawa do poszanowania życia prywatnego i rodzinnego, domu oraz komunikowania się, ochrony danych osobowych, wolności myśli, sumienia i religii, wolności wypowiedzi i informacji, wolności prowadzenia działalności gospodarczej, prawa do skutecznego środka prawnego i dostępu do bezstronnego sądu oraz różnorodności kulturowej, religijnej i językowej (motyw 4). Potwierdza to, że dane osobowe nie są dobrami hierarchicznie ważniejszymi od innych. Przeciwnie, z unormowań zarówno konstytucji, jak i KPP można wysnuć wniosek, że w razie kolizji uniemożliwiającej pełną realizację pozostających w zbiegu praw i wolności prawo do ochrony danych osobowych nie ma pierwszeństwa. Dotyczy to głównie kolizji z wolnością komunikowania się, wolnością słowa oraz pozyskiwania i rozpowszechniania informacji.

W stosunku do niektórych praw i wolności prawo do ochrony danych osobowych może jednak mieć charakter nadrzędny, zwłaszcza jeśli zważyć na okoliczność, że zostało ono w części bezpośrednio unormowane zarówno w konstytucji, jak i w KPP. Takie założenie zdaje się wyrażać art. 6 ust. 1 pkt f RODO, zgodnie z którym przetwarzanie danych uznaje się za legalne, jeśli jest ono niezbędne do celów wynikających z prawnie uzasadnionych interesów realizowanych przez administratora lub przez stronę trzecią, $\mathrm{z}$ wyjątkiem sytuacji, kiedy nadrzędny charakter mają interesy lub podstawowe prawa i wolności wymagające ochrony danych osobowych, w szczególności, gdy dane dotyczą dziecka. Mimo że pojęcia prawnie uzasadnionych interesów nie należy utożsamiać wyłącznie z realizacją określonego prawa podmiotowego, to jednak nie powinno ulegać wątpliwości, że na podstawie własnego prawa można legalnie przetwarzać cudze dane osobowe, jeśli prawa osoby, której dane dotyczą, w konkretnym przypadku nie mają charakteru nadrzędnego. Pojęcie prawnie uzasadnionych interesów ma jednak znacznie szersze znaczenie, ponieważ — jak przyjmuje się $\mathrm{w}$ doktrynie - mogą one wynikać również z prawa w rozumieniu przedmiotowym i mieć charakter wyłącznie faktyczny czy ekonomiczny ${ }^{13}$.

W każdym razie przetwarzanie danych osobowych nie może wykraczać poza cel niezbędny dla zrealizowania prawnie uzasadnionych interesów i zasadniczo powinno

temat G. Sibiga, Dopuszczalny zakres polskich przepisów o ochronie danych osobowych po rozpoczęciu obowiazywania ogólnego rozporządzenia o ochronie danych — wybrane zagadnienia, „Monitor Prawniczy” 2016, nr 20, s. 16 i n. (dodatek); P. Kozik, Zakres swobody regulacyjnej państw członkowskich przy wdrażaniu ogólnego rozporządzenia o ochronie danych osobowych do prawa krajowego, „Europejski Przegląd Sądowy" 2017, nr 5, s. 18 i n.

13 Vide np. A. Nerka, M. Sakowska-Baryła, komentarz do art. 6 RODO, [w:] Ogólne rozporządzenie o ochronie danych osobowych. Komentarz, red. M. Sakowska-Baryła, Warszawa 2018 r.; P. Litwiński, P. Barta, M. Kawecki, komentarz do art. 6 RODO, [w:] Rozporządzenie UE w sprawie ochrony osób fizycznych $w$ zwiazku z przetwarzaniem danych osobowych i swobodnym przeplywie takich danych. Komentarz, red. P. Litwiński, Warszawa 2018 r. Odnośnie do poprzednio obowiązującego stanu prawnego vide J. Barta, P. Fajgielski, R. Markiewicz, Ochrona danych osobowych. Komentarz, Warszawa 2015, s. 468 i n. 
służyć tylko im (zob. art. 6 ust. 1 i 4 RODO). Wniosek ten wynika również z konieczności rozgraniczenia kolizyjnych praw i wolności w sposób zapewniający ich możliwie pełne urzeczywistnienie. Oceny niezbędności przetwarzania danych osobowych w celu realizowania uzasadnionych interesów zawsze należy dokonywać przy uwzględnieniu okoliczności konkretnych przypadków, niemniej jednak sytuacje wątpliwe powinno się rozstrzygać na korzyść realizacji nadrzędnych praw i wolności. Z uwagi na dużą drobiazgowość regulacji poświęconej ochronie danych osobowych w porównaniu z unormowaniem kolizyjnych praw i wolności (np. wolnością komunikowania się, wolnością słowa oraz pozyskiwania $\mathrm{i}$ rozpowszechniania informacji) $\mathrm{w}$ praktyce ich stosowania mogą wystąpić istotne problemy interpretacyjne. Jeśli przyjąć, zgodnie z motywem 4 preambuły RODO, że wymieniona regulacja nie narusza praw podstawowych, wolności i zasad określonych w KPP oraz zapisanych w traktatach, to przewidziana w niej ochrona danych osobowych powinna być realizowana tylko o tyle, o ile faktycznie nie koliduje z tymi prawami, wolnościami i zasadami.

Niemniej art. 23 ust. 1 RODO, dozwalający na pewne odstępstwa w wyznaczonym standardzie ochrony danych osobowych, wymaga jednak od prawa unijnego oraz prawa państw członkowskich UE, aby ich przepisy odpowiadały uprawnieniom i obowiązkom przewidzianym $\mathrm{w}$ art. 12-22, były środkiem niezbędnym i proporcjonalnym oraz nie naruszały istoty podstawowych praw i wolności. Te dwa założenia wykluczają się wzajemnie nawet wówczas, gdy uwzględni się reguły metaprawne dotyczące czasu obowiązywania kolizyjnych regulacji. Przykładowo nie jest możliwe zapewnienie jednoczesnej realizacji prawa do bycia zapomnianym oraz wolności pozyskiwania i przekazywania informacji czy wolności słowa (zob. art. 23 ust. $1 \mathrm{w}$ zw. z art. 17 ust. 3 pkt a i art. 85 RODO oraz art.11 ust. $1 \mathrm{KPP}$ w zw. z art. 54 ust. 1 konstytucji). Biorąc pod uwagę, że akty prawne niższej rangi nie powinny być sprzeczne $\mathrm{z}$ aktami hierarchicznie wyżej usytułowanymi w systemie prawa, a także mając na względzie rezultaty wykładni funkcjonalnej, wydaje się, że wymóg, aby regulacje unijne i krajowe odpowiadały prawom i obowiązkom przewidzianym w art. 12-22 RODO, należy odnosić jedynie do ich zasadniczej zgodności z wymienionymi przepisami ${ }^{14}$ oraz wyłącznie do sytuacji, w których inne chronione prawa i wolności nie mają charakteru nadrzędnego.

\section{ZASTRZEŻENIA WOBEC SPOSOBU NORMOWANIA SANKCJI}

Niewątpliwie wykładnia przepisów o ochronie danych osobowych w pewnym stopniu powinna zniwelować rygoryzm regulacji, niemniej jednak mimo zabiegów interpretacyjnych szeroki zakres i duża nieostrość unormowań stanowiących podstawę prawną sankcji za ich naruszenie każą zastanowić się nad poprawnością założeń obowiązujących przepisów oraz ich zgodnością z konstytucją i KPP. Przede wszystkim zasadnicze wątpliwości budzi normatywne pominięcie zrównoważonej ochrony różnych praw i wolności, rozmycie regulacji, brak koncentracji na zapobieganiu najistotniejszych nadużyć

${ }^{14}$ Chodzi o niedopuszczalność ingerowania w istotę prawa do ochrony danych osobowych. Obiektywnie nie jest bowiem możliwe zarówno ograniczenie zakresu praw i obowiązków wymienionych w art. 12-22 RODO, jak i zapewnienie przestrzegania tych przepisów. 
i zwalczaniu najbardziej niebezpiecznych i masowych zjawisk występujących przy przetwarzaniu danych osobowych, a także widoczna presja na ograniczenie i likwidację tradycyjnego obrotu na rzecz obrotu elektronicznego, jako rzekomo bardziej bezpiecznego w kontekście przetwarzania danych osobowych ${ }^{15}$. Nie ma wystarczających ani dostatecznie uzasadnionych powodów, aby sankcjonować każde naruszenie przepisów o ochronie danych osobowych. W szczególności nie przemawia za tym zasada równego traktowania, ponieważ odnosi się ona tylko do podmiotów charakteryzujących się jednakowo istotnymi cechami indywidualizującymi ${ }^{16}$. Poza tym rozwiązanie takie przynosi znaczenie więcej negatywnych niż pozytywnych efektów, czego powszechnie możemy doświadczyć sami, a także pośrednio, obserwując liczne doniesienia medialne dotyczące wielu absurdów przy wdrażaniu RODO ${ }^{17}$. Wobec wadliwie skonstruowanych przepisów na niewiele zdają się apele urzędników, aby zachować rozsądek przy stosowaniu przepisów o ochronie danych osobowych. Strach przed dotkliwością odpowiedzialności doprowadził już do zaniechania lub ograniczenia świadczenia wielu usług oraz gwałtownego wzrostu popularności różnego rodzaju usług informatyczno-konsultingowych w znacznie wyższym stopniu niż przy wdrażaniu i stosowaniu dyrektyw dotyczących zagadnienia usług społeczeństwa informacyjnego ${ }^{18}$. Niewykluczone, że na ostateczny kształt

${ }^{15}$ Mimo ciągłego wzrostu nakładów na zapewnienie bezpieczeństwa obrotu elektronicznego statystycznie dochodzi w nim jednak do nieporównywalnie większej liczby naruszeń poufności danych oraz szkód materialnych niż w obrocie tradycyjnym. Zagrożenie wyciekiem danych w obrocie elektronicznym ma też charakter masowy, co istotnie wpływa na ocenę stopnia bezpieczeństwa obrotu. Wymownym przykładem wskazanej prawidłowości jest poziom bezpieczeństwa korespondencji pocztowej w obrocie tradycyjnym i elektronicznym.

${ }^{16}$ Zasada równości wobec prawa nie oznacza wcale konieczności przyznawania wszystkim kategoriom podmiotów takich samych praw i obowiązków, lecz jedynie od strony pozytywnej wskazuje, że wszystkie podmioty indywidualizowane za pomocą danej istotnej cechy charakterystycznej powinny być traktowane według jednakowej miary, bez faworyzowania lub dyskryminowania żadnej z nich. Zasadę równości wyznacza również od strony negatywnej waga istotności kryteriów różnicujących podmioty. Samo odstępstwo od ustalonego ich kręgu na podstawie cech pozytywnych nie oznacza bowiem jeszcze naruszenia zasady równego traktowania, jeśli zastosowane kryteria różnicujące krąg podmiotów są co najmniej w jednakowym stopniu istotne. Konieczne stają się więc dodatkowe ustalenia, w szczególności czy zastosowane kryterium różnicowania pozostaje w racjonalnym związku z celem i treścią danej regulacji, czy waga interesu, któremu różnicowanie podmiotów ma służyć, pozostaje w odpowiedniej proporcji do wagi interesów, które mogłyby zostać naruszone w wyniku wprowadzonego różnicowania, oraz czy zastosowane kryterium różnicowania pozostaje w związku z innymi wartościami, zasadami oraz normami uzasadniającymi odmienne traktowanie podmiotów podobnych. Vide odnoszące się do tak rozumianej zasady równości wyroki TK: z 20 października 1998 r., sygn. akt K 7/98, OTK ZU 1998/6/96; z 15 września 1999 r., sygn. akt K 11/99, OTK ZU 1999/6/116.

${ }_{17}$ Vide $\mathrm{np} .<$ https://bezprawnik.pl/absurdy-rodo-10-najwiekszych/, https://www.rp.pl/Dane-osobowe/ 309219953-Absurdy-RODO-ksywki-zamiast-nazwisk-jako-identyfikatory-pacjentow.html>, dostęp 15 VIII 2019.

${ }_{18}$ Confer zwłaszcza dyrektywę 2000/31/WE Parlamentu Europejskiego i Rady z dnia 8 czerwca 2000 r. w sprawie niektórych aspektów prawnych usług społeczeństwa informacyjnego, w szczególności handlu elektronicznego w ramach rynku wewnętrznego (dyrektywa o handlu elektronicznym, Dz.U. UE L 2000.178.1) oraz dyrektywę 2002/58/WE Parlamentu Europejskiego i Rady z dnia 12 lipca 2002 r. dotyczącą przetwarzania danych osobowych i ochrony prywatności w sektorze łączności elektronicznej (dyrektywa o prywatności i łączności elektronicznej, Dz.U. UE L 2002.201.37). 
rozwiązań przyjętych w RODO duży wpływ miały branżowe działania lobbingowe. Odwracanie uwagi od kwestii niedostatecznej skuteczności narzędzi zapobiegających najniebezpieczniejszym zagrożeniom oraz zwalczających największe nadużycia przy przetwarzaniu danych osobowych, zwłaszcza w sposób zautomatyzowany i z użyciem profilowania lub sztucznej inteligencji, powinno jednak budzić refleksję i zastanowienie (por. art. 25 RODO).

Warto też zwrócić uwagę, że mimo restrykcyjności przepisów o ochronie danych osobowych bardzo łatwo jest wprowadzić tak na rynek krajowy, jak i europejski różnego rodzaju sprzęt i oprogramowanie, które nierzadko gromadzą i przekazują dane osobowe użytkowników bez ich wiedzy i zgody, a ponadto nie spełniają wymogów bezpieczeństwa poufności przechowywanych danych. Obciążanie odpowiedzialnością za naruszenie przepisów o ochronie danych osobowych wyłącznie lub w głównej mierze użytkowników takiego oprzyrządowania wydaje się niewłaściwe ${ }^{19}$. Mając na względzie te wszystkie zastrzeżenia, należy bliżej przyjrzeć się, czy przepisy sankcjonujące naruszenie przepisów o ochronie danych osobowych są zgodne z konstytucją.

\section{SANKCJE KARNE}

W pierwszej kolejności pytanie o konstytucyjność należy odnieść do przepisów ustawy o ochronie danych osobowych przewidujących sankcje karne. Prawo unijne nie reguluje tego typu sankcji, nie wymaga bezwzględnie ani też nie zabrania ich wprowadzenia. Zgodnie z art. 84 ust. 1 RODO państwa członkowskie przyjmują przepisy określające sankcje za naruszenia niepodlegające karom pieniężnym oraz podejmują wszelkie środki niezbędne do ich wykonania, zapewniając ich skuteczność, proporcjonalność oraz realizację funkcji odstraszających. Literalne brzmienie art. 84 ust. 1 RODO może wprawdzie sugerować odmienny wniosek, jednak wydaje się, że przepis ten nie przesądza wcale o stanowczym obowiązku przyjęcia w prawodawstwie krajowym dodatkowych sankcji ani ich określonego rodzaju, a jedynie przewiduje powinność warunkową, aby w razie ich uzasadnionego ustanowienia odpowiadały one przyjętemu w RODO standardowi sankcji skutecznych, proporcjonalnych i odstraszających. Na taką wykładnię wskazuje motyw 152 preambuły RODO stanowiący, że „w sytuacjach, w których niniejsze rozporządzenie nie harmonizuje sankcji administracyjnych, lub w razie potrzeby w innych przypadkach, na przykład w razie poważnego naruszenia niniejszego rozporządzenia, państwa członkowskie powinny wdrożyć system przewidujący skuteczne, proporcjonalne i odstraszające sankcje. Charakter takich sankcji (karny lub administracyjny) powinno określać prawo państwa członkowskiego".

Zważywszy na okoliczność, że naruszenie przepisów o ochronie danych osobowych jest obecnie w Polsce sankcjonowane odpowiedzialnością cywilną, administracyjną, karno-administracyjną oraz karną trzeba zastanowić się, czy sankcje te nie są nadmierne, zwłaszcza wobec bardzo szerokiego ujęcia strony przedmiotowej czynów

${ }^{19}$ Władze publiczne sprzyjają rozwojowi technologii informatycznych, niemniej z niezrozumiałych pobudek tolerują jednak różne formy ograniczania oraz wyłączania odpowiedzialności producentów za bezpieczeństwo danych. 
karalnych oraz jednoczesnego zagrożenia takich czynów wysokimi karami pieniężnymi w ramach odpowiedzialności administracyjno-karnej przewidzianej w RODO. Zgodnie $\mathrm{z}$ art. 107 ust. 1 u.o.d.o. każdy, kto przetwarza dane osobowe, choć ich przetwarzanie nie jest dopuszczalne albo do ich przetwarzania nie jest uprawniony, podlega sankcji grzywny, ograniczenia wolności lub pozbawienia wolności do lat dwóch, a w przypadku, gdy czyn dotyczy tzw. danych wrażliwych, podlega sankcji grzywny, ograniczenia wolności lub pozbawienia wolności do lat trzech. Niezależnie od strony podmiotowej przestępstwa penalizowanie każdego rodzaju przetwarzania danych osobowych bez uzasadnionej podstawy prawnej lub z przekroczeniem niezbędności celu przetwarzania jest niezgodne z motywem 152 preambuły RODO, dotyczącym ustanowienia sankcji dodatkowych w krajowym porządku prawnym. Znamiona przedmiotowe czynów karalnych w zasadzie obejmują każde naruszenie RODO, a nie wyłącznie poważne, o odpowiednio dużym ciężarze gatunkowym i rozmiarze. Co więcej, mimo pełnej zastosowalności sankcji administracyjnych i karno-administracyjnych przewidzianych w RODO pokrywają się one ze znamionami czynów sankcjonowanych wielkimi karami pieniężnymi, co z jednej strony jeszcze bardziej zwiększa dolegliwość sankcji, z drugiej zaś odwraca uwagę od zwalczania czynów najbardziej niebezpiecznych, w szczególności związanych z różnymi formami automatycznego profilowania danych osobowych.

Nakładanie się znamion czynów zagrożonych sankcjami karno-administracyjnymi i karnymi choć jest - co do zasady — dopuszczalne, to jednak znaczny zakres ich części wspólnej oraz wypełnianie funkcji represyjnej istotnie zwiększa ryzyko naruszenia zasady ne bis in idem ${ }^{20}$, zakazującej zarówno w prawie unijnym, jak i krajowym prowadzenia postępowań w sprawach prawomocnie osądzonych za ten sam czyn (art. $50 \mathrm{KPP}$ oraz art. 2 konstytucji ${ }^{21}$ ). Wskazana okoliczność może dodatkowo wzmacniać zarzut dotyczący nadmierności sankcji karnej, wywodzony zarówno w oderwaniu od naruszenia konkretnych konstytucyjnych praw podmiotowych na podstawie art. 2 konstytucji, jak i w powiązaniu z nimi na podstawie art. 31 ust. 1 konstytucji. Nadmierność sankcji karnej, o której mowa w art. 107 ust. 1 u.o.d.o., wynika jednak głównie z nazbyt szerokiego i zarazem niedostatecznie określonego stypizowania znamion strony przedmiotowej czynów sankcjonowanych odpowiedzialnością karną. Dość stwierdzić, że sankcją karną zostały objęte czyny, które nie wyrządzają żadnej szkody majątkowej lub niemajątkowej, nie mówiąc już o szkodzie odpowiednich

${ }^{20}$ Confer M. Górski, komentarz do art. 84 RODO, [w:] Ogólne rozporządzenie..., oraz P. Litwiński, P. Barta, M. Kawecki, komentarz do art. 84 RODO, [w:] Rozporządzenie UE w sprawie ochrony osób fizycznych...

${ }^{21}$ Zasadę ne bis in idem w ujęciu konstytucyjnym wywodzi się zarówno w doktrynie, jak i w judykaturze ze standardów demokratycznego państwa prawa np. wyrok TK z 8 października 2002 r., sygn. akt K 36/00, OTK ZU 2002/5A/63. Możliwość zastosowanie tej zasady przy zbiegu sankcji karnych i administracyjnych potwierdził TK m.in. w wyroku z 29 kwietnia 1998 r., sygn. akt K 17/97, OTK ZU 1998/3/30 oraz w wyroku z 4 września 2007 r., sygn. akt P 43/06, OTK ZU 2007/8/95; confer także wyroki TK: z 1 lipca 2014 r., sygn. akt SK 6/12, OTK ZU 2014/7A/68; z 21 października 2015 r., sygn. akt P 32/12, OTK ZU 2015/9A/148 (wraz ze zdaniami odrębnymi W. Hermelińskiego i T. Liszcz); oraz z 11 października 2016 r., sygn. akt K 24/15, OTK ZU 2016/A/77. 
rozmiarów. Zgodnie z konstytucyjnym wymogiem proporcjonalności powinna istnieć adekwatność celu i środka użytego do jego osiągnięcia, natomiast w analizowanym przypadku ona nie występuje. $Z$ jednej strony interes publiczny nie wymaga w sposób konieczny i niezbędny penalizowania wszystkich naruszeń, z drugiej zaś takie rozwiązanie nie jest w pełni skuteczne, ponieważ w praktyce drobniejsze przestępstwa faktycznie nie są ścigane. Taki stan rzeczy stanowi jednak zagrożenie dla pewności prawa i bezpieczeństwa obrotu. Jest także wystarczającym powodem uzasadniającym stwierdzenie niezachowania odpowiednich proporcji między zakładanymi efektami regulacji art. 107 ust. 1 u.o.d.o. a skalą ograniczeń konstytucyjnych praw i wolności oraz reakcją państwa na jej naruszenie.

Nadmierność sankcji karnej wzmacniana jest nie tylko zakresowym nakładaniem się znamion czynów zagrożonych jednocześnie sankcjami karno-administracyjnymi, ale również niedostatecznie precyzyjnym określeniem ich strony przedmiotowej. Wymóg należytej określoności przepisów ma doniosłe znaczenie zwłaszcza w kontekście norm prawa karnego, które z uwagi na swoje represyjno-prewencyjne funkcje oraz konstytucyjne gwarancje ochrony praw i wolności powinny zapewniać większe poczucie jednoznaczności i pewności. $Z$ tego względu wymóg określoności może również stanowić samodzielną podstawę oceny konstytucyjności przepisów, odrębną od kwestii nieproporcjonalności i nadmierności sankcji. Jest on głównie wywodzony z art. 2 konstytucji, ale jako jeden z elementów demokratycznego państwa prawnego, funkcjonalnie powiązany z zasadami ochrony zaufania do państwa oraz pewności i bezpieczeństwa prawa, wymóg określoności może jednak łączyć się także z treścią poszczególnych praw i wolności oraz podlegać łącznie z nimi ochronie w ramach standardu proporcjonalności na podstawie art. 31 ust. 3 konstytucji. W orzecznictwie Trybunału Konstytucyjnego wymóg określoności przepisów postrzega się nie tylko jako nakaz zachowania odpowiedniej ich precyzji zapewniającej zrozumiałość treści i jednolitą wykładnię, ale również jako zakaz tworzenia przez organy stosujące prawo za pomocą niejasnych sformułowań nazbyt szerokich ram umożliwiających dowolność interpretacji lub nadmierną jej swobodę ${ }^{22}$. O ile więc znamiona czynów karalnych mogą zawierać zwroty nieostre i ocenne, o tyle powinny one zawsze gwarantować pewność i przewidywalność rekonstrukcji normy prawnokarnej. Wydaje się, że penalizowanie każdego niedopuszczalnego lub nieuprawnionego przetwarzania danych osobowych można zakwalifikować jako przejaw niedostatecznej określoności przepisów, zwłaszcza że mogą być one wynikiem bardzo różnych i niczym nieograniczonych zdarzeń, a także następstwem przyjęcia błędnych założeń odnośnie do ochrony konkretnych danych osobowych oraz pozostających z nimi w kolizji innych konstytucyjnych praw i wolności.

${ }^{22} \mathrm{~W}$ kwestii sposobu rozumienia dostatecznej określoności przepisów vide Proces prawotwórczy $w$ świetle orzecznictwa Trybunału Konstytucyjnego. Wypowiedzi Trybunalu Konstytucyjnego dotyczace zagadnień zwiazanych z procesem legislacyjnym, Warszawa 2015 r., s. 62 i n. oraz I. Chojnacka, Zasada przyzwoitej legislacji w orzecznictwie Trybunału Konstytucyjnego, „Zagadnienia Sądownictwa Konstytucyjnego" 2011, nr 1, s. 97 i n. 
Istotne wątpliwości wywołuje także art. 107 ust. 2 u.o.d.o. ${ }^{23}$, którym spenalizowano brak współdziałania $\mathrm{z}$ organem kontrolnym w sprawach ochrony danych osobowych. Zgodnie z tym przepisem odpowiedzialności karnej sankcjonowanej grzywną, karą ograniczenia wolności albo pozbawienia wolności do lat dwóch podlega również ten, kto w związku z toczącym się postępowaniem w sprawie nałożenia administracyjnej kary pieniężnej nie dostarcza danych niezbędnych do określenia podstawy wymiaru administracyjnej kary pieniężnej lub dostarcza dane, które uniemożliwiają ustalenie podstawy wymiaru administracyjnej kary pieniężnej. Należy mieć bowiem na względzie, że w ustawie o ochronie danych osobowych zawarto odesłanie w zakresie odmiennie nieunormowanym do kodeksu postępowania administracyjnego [dalej: k.p.a. $]^{24}$, a ten gwarantuje zarówno świadkom, jak i stronom postępowania prawo odmowy zeznań i odpowiedzi na pytania (art. 7 ust. 3 u.o.d.o. w zw. z art. 83 § 2 i 3 oraz art. 86 k.p.a.). Zapewnienie skuteczności postępowania w sprawach o nałożenie kary pieniężnej nie uzasadnia penalizacji zwłaszcza w tak szerokim zakresie. Należy przypomnieć, że RODO wymaga od ustawodawstw państw członkowskich UE sankcji skutecznych i odstraszających tylko w razie istotnego naruszenia przepisów, dodatkowe sankcje powinny być proporcjonalne (np. motyw 152 RODO). Zachowanie wymogu proporcjonalności w zakresie regulacji praw i obowiązków zawarto również w art. 31 ust. 3 konstytucji. Wydaje się, że przepis art. 107 ust. 2 u.o.d.o. nie spełnia tego standardu prawidłowej legislacji.

Podobne zastrzeżenia budzi ponadto art. 108 u.o.d.o., zgodnie z którym każdy, kto udaremnia lub utrudnia kontrolującemu prowadzenie kontroli przestrzegania przepisów o ochronie danych osobowych, podlega karze grzywny ograniczenia wolności albo pozbawienia wolności do lat dwóch. Chodzi o to, że we wskazanym przepisie przewidziano tak samo dolegliwą sankcję, jak w przypadku ujawnienia tajemnicy zawodowej (art. 266 § 1 kodeksu karnego; dalej: k.k.) ${ }^{25}$, co w przypadku wystąpienia kolizji między różnymi prawnie chronionymi dobrami może prowadzić do poświęcenia jednych kosztem ochrony drugich. Tymczasem ochrona danych osobowych powinna być realizowana tylko w takim zakresie, w jakim nie narusza ochrony tajemnicy zawodowej. Takie założenie wyrażono w art. 64 u.o.d.o., zgodnie z którym prezes Urzędu Ochrony Danych Osobowych ma prawo - w celu realizacji swoich zadań — dostępu do informacji objętych tajemnicą prawnie chronioną, chyba że przepisy szczególne stanowią inaczej. Natomiast według przepisów szczególnych przykładowo adwokat i radca prawny zobowiązani są zachować w tajemnicy wszystko, o czym dowiedzieli się w związku

${ }^{23}$ Przepis ten został wprowadzony do porządku prawnego na mocy ustawy z dnia 21 lutego 2019 r. o zmianie niektórych ustaw w związku z zapewnieniem stosowania rozporządzenia Parlamentu Europejskiego i Rady (UE) 2016/679 z dnia 27 kwietnia 2016 r. w sprawie ochrony osób fizycznych w związku z przetwarzaniem danych osobowych i w sprawie swobodnego przepływu takich danych oraz uchylenia dyrektywy 95/46/WE (ogólne rozporządzenie o ochronie danych; Dz.U. z 2019 r. poz. 730).

${ }^{24}$ Ustawa z dnia 14 czerwca 1960 r. — Kodeks postępowania administracyjnego (tekst jedn. Dz.U. z 2018 r. poz. 2096).

${ }^{25}$ Ustawa z dnia 6 czerwca 1997 r. — Kodeks karny (Dz.U. z 1997 r. nr 88, poz. 553, ze zm.). 
z udzieleniem pomocy prawnej ${ }^{26}$. Mimo formalnie przyznanego pierwszeństwa ochrony tajemnicy zawodowej, faktycznie może ona podlegać nieuzasadnionym ograniczeniom. Sankcjonowanie naruszeń przewidzianych w art. 108 u.o.d.o. i w art. $266 \S 1$ k.k. jednakowym zagrożeniem wyzwala bowiem postawy konformistyczne istotnie osłabiające ochronę tajemnicy zawodowej. Z systemowego punktu widzenia wydaje się więc, że sankcja przewidziana w art. 108 u.o.d.o. powinna być mniejsza albo sankcja przewidziana w art. $266 \S 1$ k.k. surowsza, zwłaszcza że w sprawach istotnej wagi w ramach procedury karnej może dojść do sądowego zwolnienia z obowiązku zachowania tajemnicy zawodowej ${ }^{27}$. Przy tworzeniu sankcji przypisanej do art. 108 u.o.d.o. wydaje się, że ustawodawca nie zachował odpowiedniej proporcji między chronionymi dobrami prawnymi, w rezultacie czego można przyjąć, że zachodzi podejrzenie naruszenia gwarancji prawidłowej legislacji wynikającej z treści art. 2 i 31 ust. 3 konstytucji. Oceny tej nie zmienia nowelizacja ustawy Prawo o adwokaturze oraz ustawy o radcach prawnych, w których wprowadzono wyłączenie stosowania niektórych przepisów RODO podyktowane ochroną tajemnicy zawodowej (art. 16a ust. 1 i 2 u.p.a. oraz art. 5a ust. 1 i 2 u.r.p.), a nawet wyraźne przesądzono o tym, że obowiązek zachowania tajemnicy zawodowej adwokata i radcy prawnego nie ustaje w przypadku, gdy z żądaniem ujawnienia informacji uzyskanych w związku z udzieleniem przez nich pomocy prawnej występuje prezes Urzędu Ochrony Danych Osobowych (art. 16b u.p.a. i art. 5b u.r.p.). Poza tym ustawodawca nie przewidział podobnych rozwiązań wobec innych dysponentów tajemnicy zawodowej, np. rzeczników patentowych.

\section{SANKCJE KARNO-ADMINISTRACYJNE}

Poważne wątpliwości odnośnie do zachowania standardów konstytucyjnych wywołują ponadto sankcje karno-administracyjne przewidziane w RODO ${ }^{28}$. Dotyczą one nie tylko kwestii nadmiernych kar pieniężnych oraz niedostatecznej określoności przepisów sankcjonowanych tymi karami, ale również równego traktowania. Według założenia art. 83 ust. 1 RODO kary pieniężne powinny być w każdym indywidualnym przypadku skuteczne, proporcjonalne i odstraszające, natomiast zgodnie z konstytucją takie wymogi dotyczą samej regulacji prawnej, tworzącej normy generalne i abstrakcyjne. Kary pieniężne mogą być stosowane oprócz lub zamiast takich sankcji administracyjnych, jak: wydawanie ostrzeżeń; udzielanie upomnień; nakazanie spełnienia żądania osoby, której dane dotyczą; nakazanie dostosowania operacji przetwarzania danych osobowych do przepisów RODO; nakazanie zawiadomienia osoby, której dane

26 Vide art. 6 ust. 1 ustawy z dnia 26 maja 1982 r. Prawo o adwokaturze (tekst jedn. Dz.U. z 2018 r. poz. 1184; dalej: u.p.a.) oraz art. 3 ust. 3 ustawy z dnia 6 lipca 1982 r. o radcach prawnych (tekst jedn. Dz.U. z 2017 r. poz. 1870, ze zm.; dalej: u.r.p.).

${ }^{27}$ Vide art. 180 § 2 ustawy z dnia 6 czerwca 1997 r. - Kodeks postępowania karnego (tekst jedn. Dz.U. z 2017 r. poz. 1904).

${ }^{28}$ Zgodnie z charakterem rozporządzeń UE mają one bezpośrednie zastosowane w polskim porządku prawnym (art. 99 RODO). Taki skutek rozporządzeń unijnych wynika $\mathrm{z}$ art. 288 Traktatu o funkcjonowaniu Unii Europejskiej (Dz.U. z 2004 r. nr 90, poz. 864/2, ze zm.; dalej: TfUE). 
dotyczą o naruszeniu ochrony jej danych; wprowadzanie czasowego lub całkowitego ograniczenia przetwarzania, w tym zakazu przetwarzania danych osobowych; nakazanie sprostowania lub usunięcia danych osobowych bądź ograniczenia ich przetwarzania oraz nakazanie powiadomienia o tych czynnościach; cofnięcie certyfikacji lub nakazanie podmiotowi certyfikującemu cofnięcia certyfikacji lub jej nieudzielania czy nakazanie zawieszenia przepływu danych osobowych do odbiorcy w państwie trzecim lub do organizacji międzynarodowej (art. 83 ust. $1 \mathrm{w}$ zw. $\mathrm{z}$ art. 58 ust. 2 pkt a-h i j RODO).

Kumulatywny charakter kar pieniężnych niewątpliwie wpływa na zwiększenie dolegliwości sankcji, niemniej jednak już sama ich rozpiętość i wysokość mogą budzić pewne zastrzeżenia w kontekście wymogu proporcjonalności oraz nadmiernego zakresu swobody ustalania przez właściwe organy ich indywidualnego wymiaru. Są one tym większe, im większy stopień nieokreśloności mają przepisy będące materialnoprawną podstawą nakładania kar pieniężnych oraz bardziej zróżnicowany jest ich ciężar gatunkowy. W zależności od naruszeń poszczególnych przepisów RODO kary pieniężne mogą zostać orzeczone w wysokości do $10 \mathrm{mln}$ euro lub do $20 \mathrm{mln}$ euro, a w przypadku przedsiębiorstwa w wysokości do $2 \%$ lub do $4 \%$ jego całkowitego rocznego światowego obrotu z poprzedniego roku obrotowego, przy czym w każdym razie zastosowanie ma kwota wyższa (art. 83 ust. 4 i 5 RODO). Natomiast za nieprzestrzeganie już orzeczonego nakazu maksymalny przedział kary pieniężnej określono odpowiednio do kwoty 20 mln euro, a w przypadku przedsiębiorstwa do kwoty odpowiadającej 4\% jego całkowitego rocznego światowego obrotu z poprzedniego roku obrotowego, przy czym również i w takiej sytuacji zastosowanie ma zawsze kwota wyższa (art. 83 ust. 6 RODO). Tak duża rozpiętość administracyjnych kar pieniężnych przewidzianych za naruszenie niedostatecznie sprecyzowanych obowiązków wydaje się w świetle konstytucyjnych gwarancji proporcjonalności nadmierna niezależnie od ich indywidualnego wymiaru.

\section{KONSTYTUCYJNE GWARANCJE OCHRONY PRAW I WOLNOŚCI W KONTEKŚCIE PRAWA UNIJNEGO}

Relacja prawa unijnego do prawa krajowego, w szczególności w zakresie oceny konstytucyjności i jej rezultatów, jest dyskusyjna ${ }^{29}$. Z jednej strony art. 90 ust. 1 konstytucji w niektórych sprawach dopuszczono umową międzynarodową przekazanie UE lub innej organizacji międzynarodowej kompetencji organów władzy państwowej,

${ }^{29}$ Vide w szczególności K. Wójtowicz, Sądy konstytucyjne wobec prawa Unii Europejskiej, „Monografie Konstytucyjne” 2012, nr 3, s. 55 i n.; B. Banaszak, Zasada nadrzędności Konstytucji w polskim porzadku prawnym, [w:] Zasada pierwszeństwa prawa Unii Europejskiej w praktyce działania organów władzy publicznej, red. M. Jabłoński, S. Jarosz-Żukowska, „Prace Naukowe Wydziału Prawa, Administracji i Ekonomii Uniwersytetu Wrocławskiego" 2015, nr 58, s. 41 i n. (seria e-Monografie); M. Jabłoński, S. Jarosz-Żukowska, Kontrola konstytucyjności prawa pochodnego w trybie skargi konstytucyjnej i pytań prawnych, [w:] Zasada pierwszeństwa prawa Unii Europejskiej..., s. 55 i n. Confer Relacje między prawem konstytucyjnym a prawem unijnym w orzecznictwie sąów konstytucyjnych państw Unii Europejskiej, red. K. Zaradkiewicz, Warszawa 2011. 
w tym dotyczących stanowienia prawa, a $\mathrm{z}$ drugiej strony - zgodnie $\mathrm{z}$ art. 8 - to konstytucja jest najwyższym prawem w Rzeczypospolitej Polskiej. Nie bez wątpliwości przyjmuje się także kognicję TK nie tylko w sprawach badania zgodności z konstytucją prawa pierwotnego UE, ale również prawa wtórnego, tworzonego w ramach przekazanych jej kompetencji. O ile bowiem zarówno w konstytucji (art. 188 pkt 1), jak i w ustawie o organizacji i trybie postępowania przed Trybunałem Konstytucyjnym [dalej: u.o.t.k.] przewidziano wprost orzekanie o zgodności umów międzynarodowych z konstytucją (art. 33 ust. 1 pkt 1) ${ }^{30}$, o tyle ustalenie kognicji TK w sprawach badania konstytucyjności prawa wtórnego UE wymaga wykładni systemowej i funkcjonalnej. Właściwość TK w tych sprawach została jednak potwierdzona w doktrynie i orzecznictwie ${ }^{31}$.

Prawo unijne i krajowe powinno pozostawać ze sobą w zgodności i - mimo dopuszczalnych odrębności - tworzyć jednolity i spójny system prawny. Twierdzenie to znajduje wyraźne potwierdzenie w orzecznictwie TK, który już w tzw. wyroku akcesyjnym podkreślił, że oba porządki prawne: unijny i krajowy muszą „koegzystować na zasadzie obopólnie przyjaznej wykładni i kooperatywnego współstosowania"32. W osiągnięciu tego celu mogą być pomocne m.in. wspólne wartości wyrażone w konstytucjach krajów członkowskich oraz w KPP. Poza różnicami słowno-językowymi w zasadniczej części są one zgodne i przeważnie umożliwiają spójną, proeuropejską i prokonstytucyjną wykładnię przepisów, zarówno prawa unijnego, jak i krajowego. Utrzymanie spójności systemowej w dużej mierze jest zasługą prejudycjalnej współpracy sądów oraz trybunałów konstytucyjnych z Trybunałem Sprawiedliwości UE, który orzeka o zgodności prawa krajowego z prawem unijnym. Nie zawsze jednak da się pogodzić oba porządki prawne i wówczas może dochodzić do ich kolizji. Wówczas, jak zaznaczył Trybunał Konstytucyjny w wyroku akcesyjnym, możliwe są zasadniczo trzy rozwiązania: zmiana konstytucji, zmiana regulacji wspólnotowej albo wystąpienie z UE ${ }^{33} \mathrm{~W}$ zdecydowanej większości przypadków kolizje są rozwiązywane na korzyść prawa unijnego, które zgodnie z zawartymi traktatami międzynarodowymi generalnie ma pierwszeństwo przed prawem krajowym. Państwa członkowskie mają jednak zapewnioną możliwość wystąpienia do sądów unijnych ze skargą na legalność aktów unijnego prawa wtórnego (art. 263 TfUE), w porządku wewnętrznym mogą też badać ich konstytucyjność. Brakuje im jednak kompetencji do zawieszenia obowiązywania prawa unijnego ze skutkiem wobec wspólnoty europejskiej. W sytuacji, w której sądy krajowe lub trybunały konstytucyjne państw członkowskich stwierdzą niezgodność

${ }^{30}$ Ustawa z dnia 30 listopada 2016 r. o organizacji i trybie postępowania przed Trybunałem Konstytucyjnym (Dz.U. z 2016 r. poz. 2072, ze zm.).

31 Vide wyrok TK z 16 listopada 2011 r., sygn. akt SK 45/09, OTK ZU 2011/9A/93 oraz powołaną tam literaturę. Confer Zasada pierwszeństwa prawa wspólnotowego $w$ krajowych porzadkach prawnych wedlug orzecznictwa ETS i Sąu Pierwszej Instancji. Omówienia wybranych orzeczeń (1963-2005), Biuro Trybunału Konstytucyjnego 2005 r., opracowanie dostępne na $<$ http://trybunal.gov.pl/fileadmin/content/dokumenty>, dostęp 15 VII 2019.

32 Vide wyrok TK z 11 maja 2005r., sygn. akt K 18/04, OTK ZU 2005/5/49.

${ }^{33}$ Ibidem. 
prawa unijnego ze swoimi konstytucjami i pozbawią go mocy obowiązującej na swym terytorium, nie można wykluczyć, że organy unijne władne będą stwierdzić naruszenie zobowiązań traktatowych i uruchomić odpowiedzialność państwa członkowskiego (art. 258 i n. TfUE).

Taki scenariusz nie jest jednak nieuchronny, zwłaszcza jeśli weźmie się pod uwagę wysoką rangę konstytucji poszczególnych krajów członkowskich, uregulowane w nich gwarancje ochrony praw podstawowych oraz bagatelizowaną niekiedy okoliczność zawierania traktatów konstytuujących UE zgodnie z ich unormowaniami ${ }^{34}$. Także w kontekście art. 90 ust. 1 konstytucji stawianie tezy o wyższości prawa unijnego nad tym najwyższym w Polsce aktem prawnym jest wątpliwe, ponieważ umowne przekazanie kompetencji organów państwowych nastąpiło tylko w niektórych sprawach, nieobejmujących ustanowienia nowego porządku konstytucyjnego, zmiany jego istotnych gwarancji czy też skutkujących wyłączeniem stosowania konstytucji. Wydaje się, że o ile można zgodzić się z twierdzeniem, że upoważnienie do przekazania instytucjom wspólnotowym kompetencji normotwórczych obejmuje również takie, jakie przysługują ustawodawcy na podstawie art. 31 ust. 3 konstytucji, a więc również umożliwiają ingerowanie w konstytucyjne prawa i wolności, o tyle sprzeciw powinny budzić interpretacje rozszerzające jego zakres o gwarancje nienaruszalności przewidziane nie tylko w wymienionym przepisie, ale także $w$ innych przepisach konstytucji (np. art. 22 i 30 ${ }^{35}$. Możliwa jest więc sytuacja, w której stwierdzenie niekonstytucyjności unormowania unijnego nie będzie prowadziło do uruchomienia odpowiedzialności państwa członkowskiego. W orzecznictwie trybunałów konstytucyjnych państw członkowskich UE znane są przypadki stwierdzania niekonstytucyjności prawa unijnego ${ }^{36}$. Przeważnie przewija się $\mathrm{w}$ nich idea gwarancji ochrony praw podstawowych $\mathrm{w}$ zakresie nieuregulowanym przez prawodawstwo unijne oraz kwestia oczywistego sposobu naruszenia przez prawo unijne zasad ustrojowych i konstytucyjnych praw podmiotowych państw członkowskich. Nie chodzi więc o stwierdzenie jakichkolwiek sprzeczności prawa unijnego z porządkiem konstytucyjnym państw członkowskich, ale tylko tych istotnych, których w żadnym razie nie da się wyeliminować poprzez prounijną wykładnię przepisów.

\section{WYMAGANIA RODO DOTYCZĄCE STOSOWANIA SANKCJI}

Założeniem RODO jest, aby kary pieniężne stosowane za naruszenie jego przepisów w każdym indywidualnym przypadku były skuteczne, proporcjonalne i odstra-

${ }^{34}$ Confer literaturę wskazaną w przyp. 29.

${ }^{35}$ Confer S. Biernat, Glosy do wyroku Trybunału Konstytucyjnego z 11.5.2005 r. (zgodność Traktatu akcesyjnego z Konstytucja RP), K 18, glosa nr 2, „Kwartalnik Prawa Publicznego” 2005, nr 4, s. 193 i n.

${ }^{36}$ Vide np. orzecznictwo niemieckiego Federalnego Trybunału Konstytucyjnego powołane przez M. Bainczyk, Polski i niemiecki Trybunat Konstytucyjny wobec członkostwa państwa w Unii Europejskiej, „Prace Naukowe Wydziału Prawa, Administracji i Ekonomii Uniwersytetu Wrocławskiego” 2017, nr 94, s. 139 i n. (seria e-Monografie). Confer Relacje między prawem konstytucyjnym a prawem unijnym w orzecznictwie sądów konstytucyjnych państw Unii Europejskiej..., passim. 
szające (art. 83 ust. 1). W RODO sprecyzowano, że decydując się na nałożenie kary pieniężnej samoistnej lub w połączeniu $\mathrm{z}$ innymi sankcjami administracyjnymi, w konkretnych sprawach należy zwrócić uwagę na:

- charakter, wagę i czas trwania naruszenia przy uwzględnieniu charakteru, zakresu lub celu przetwarzania danych, liczby poszkodowanych osób oraz rozmiaru poniesionej przez nie szkody;

— umyślny lub nieumyślny charakter naruszenia;

- działania podjęte przez administratora lub podmiot przetwarzający w celu zminimalizowania szkody poniesionej przez osoby, których dane dotyczą;

— stopień odpowiedzialności administratora lub podmiotu przetwarzającego z uwzględnieniem wdrożonych przez nich środków technicznych i organizacyjnych zgodnie z przepisami RODO;

— wszelkie wcześniejsze naruszenia ze strony administratora lub podmiotu przetwarzającego oraz zastosowane w związku z nimi środki odpowiedzialności;

— stopień współpracy z organem nadzorczym w celu usunięcia naruszenia oraz złagodzenia jego ewentualnych negatywnych skutków;

- kategorie danych osobowych, których dotyczyło naruszenie;

— sposób, w jaki organ nadzorczy dowiedział się o naruszeniu, w szczególności czy i w jakim zakresie administrator lub podmiot przetwarzający zgłosili naruszenie;

- stosowanie zatwierdzonych kodeksów postępowania lub zatwierdzonych mechanizmów certyfikacji;

- wszelkie inne obciążające lub łagodzące czynniki mające zastosowanie do okoliczności sprawy, takie jak osiągnięte bezpośrednio lub pośrednio w związku z naruszeniem korzyści finansowe lub uniknięte straty (art. 83 ust. 2 RODO).

Ważną gwarancją indywidualnego wymiaru kar pieniężnych jest również zapewnienie, że w przypadku kumulacji naruszeń w ramach tych samych lub powiązanych operacji przetwarzania danych osobowych całkowita wysokość kary pieniężnej nie może przekraczać kary za najpoważniejsze naruszenie (art. 83 ust. 3 RODO), a także zagwarantowanie, że realizacja kompetencji organów nadzorczych podlega zabezpieczeniom proceduralnym przewidzianym $\mathrm{w}$ prawie unijnym i w prawie państw członkowskich, obejmującym prawo do skutecznego sądowego środka ochrony prawnej i rzetelnego procesu (art. 83 ust. 8 RODO). Szczególnie ta ostatnia gwarancja odgrywa istotną rolę przy ocenie konstytucyjności przepisów regulujących kary pieniężne. Jak wynika bowiem z orzecznictwa Trybunału Konstytucyjnego, niedookreśloność pojęć i zwrotów prawa materialnego powinna być rekompensowana odpowiednimi gwarancjami procesowymi $^{37}$. W tym kontekście problematyczna może być tzw. zasada rozliczalności, zgodnie z którą ciężar wykazania przestrzegania zasad odnoszących do przetwarzania danych osobowych przerzuca się na administratora danych, a także pośrednio na inne osoby (art. 5 w zw. z art. 28 RODO). Wydaje się, że zasada ta została ujęta zbyt szeroko, ponieważ obejmuje swym zakresem m.in. powinność wykazania przetwarzania danych

37 Vide np. wyrok TK z 22 czerwca 2010 r., sygn. akt SK 25/08, OTK ZU 2010/5A/51. 
zgodnie z prawem ${ }^{38}$. Jeśli więc strona postępowania nie sprosta ciężarowi dowodzenia i przy nałożeniu kary administracyjnej lub karno-administracyjnej istniejące wątpliwości zostaną rozstrzygnięte na jej niekorzyść, wówczas może dojść do oczywistego naruszenia jej praw podstawowych zagwarantowanych w konstytucji, zawierającej normy nakazujące takie wątpliwości rozstrzygać na korzyść strony, zgodnie z zasadą in dubio pro libertate (art. 2 w zw. z art. 30 i 31 ust. 3 konstytucji) ${ }^{39}$.

W pewnej mierze, ale niezupełnie, problem stosowania zasady rozliczalności w postępowaniu dotyczącym nałożenia sankcji administracyjnej można rozwiązać, korzystając z art. 7a i 77 k.p.a. ${ }^{40}$. Zgodnie z tymi przepisami w postępowaniu administracyjnym, którego przedmiotem jest nałożenie na stronę obowiązku albo ograniczenie lub odebranie uprawnienia, jeśli w sprawie pozostają wątpliwości co do treści normy prawnej, rozstrzygane są one na korzyść strony, chyba że nie pozwalają na to mające bezpośredni wpływ na wynik sprawy sporne interesy stron lub interesy osób trzecich albo ważny interes publiczny. Ponadto organ administracji publicznej jest zobowiązany zebrać i wyczerpująco rozpatrzyć materiał dowodowy. Nie można pominąć również art. 12 ustawy Prawo przedsiębiorców ${ }^{41}$, zgodnie z którym wymaga się od organu prowadzenia postępowania w sposób budzący zaufanie przedsiębiorców do władzy publicznej oraz kierowania się zasadami proporcjonalności, bezstronności i równego traktowania.

Mimo że RODO zobowiązuje do stosowania kar administracyjnych zgodnie z zasadą proporcjonalności, to jednak wymóg ten dotyczy jedynie ich indywidualnego wymiaru. Natomiast według standardów konstytucyjnych powinien on odnosić się także do samego zakresu zagrożenia sankcją oraz jego rozmiaru. Objęcie sankcją administracyjną każdego naruszenia przepisów RODO (por. art. 58 ust. 2 oraz art. 83 ust. 4-6) 42 $^{42}$ w oderwaniu od przesłanki naruszenia interesu publicznego oraz jego stopnia czy skali budzi poważne wątpliwości natury konstytucyjnej. Niewątpliwie każdy obywatel zapewne chciałby, aby jego prawa prywatne były chronione w taki sposób, niemniej jednak tak istotne wsparcie nie jest rozwiązaniem proporcjonalnym i prowadzi do wywyższania jednych praw konstytucyjnie gwarantowanych kosztem drugich oraz do nierównego traktowania obywateli. Brakuje dostatecznych podstaw oraz racji natury funkcjonalnej i celowościowej, aby każdy przypadek naruszenia przepisów RODO utożsamiać

${ }^{38}$ Domniemanie bezprawności naruszenia chronionych dóbr jest dopuszczalne, jednak wyłącznie na gruncie prawa prywatnego (confer art. 23 i 24 k.c.), natomiast ustanowienie takiego domniemania w przepisach prawa publicznego narusza standardy demokratycznego państwa prawnego.

39 In dubio pro libertate jest nie tylko jedną z metareguł tworzących zasadę demokratycznego państwa prawnego, ale również jedną z podstawowych gwarancji ochrony wolności oraz innych konstytucyjnych praw podmiotowych. Vide np. wyrok TK z dnia 27 czerwca 2008 r., sygn. akt K 52/07, OTK ZU 2008/5/88.

${ }^{40}$ Ustawa z dnia 14 czerwca 1960 r. Kodeks postępowania administracyjnego (tekst jedn. Dz.U. z 2017 r. poz. 1257 , ze zm.).

${ }^{41}$ Ustawa z dnia 6 marca 2018 r. — Prawo przedsiębiorców (Dz.U. z 2018 r. poz. 646, ze zm.).

42 Wrawdzie w odniesieniu do kar pieniężnych pozornie ten rodzaj sankcji ma odniesienie tylko do niektórych naruszeń wymienionych w art. 83 ust. 4-6, niemniej zawarte tam liczne odesłania do innych przepisów skutkują jednak de facto objęciem nimi wszystkich naruszeń dotyczących przetwarzania danych w sposób sprzeczny z prawem (np. art. 83 ust. 5a w zw. z art. 5 ust. 1 a RODO). 
z naruszeniem interesu publicznego ${ }^{43}$. Dane osobowe wywodzą się z prawa do dóbr osobistych, do kategorii których zalicza się również prawo do prywatności, a te mają charakter prywatnoprawny. Dał temu wyraz również prawodawca unijny, sankcjonując niektóre naruszenia przepisów RODO odpowiedzialnością cywilnoprawną (art. 82 RODO). Nie wyklucza to oczywiście ochrony tych dóbr również za pomocą norm prawa publicznego, niemniej jednak biorąc pod uwagę odmienne funkcje, cel i przedmiot prawa prywatnego i publicznego, nie powinno się ich utożsamiać. Niestety przesłanki odpowiedzialności publicznoprawnej za naruszania przepisów RODO, w tym również dotyczące miarkowania kar pieniężnych, o których mowa w art. 83 ust. 2 RODO, nawet pośrednio nie odwołują się do kryterium naruszenia interesu publicznego (por. art. 1 ust. 1 u.o.k.k.). Rozwiązanie to jest wadliwe i wymaga interwencji prawodawcy unijnego. W RODO doszło bowiem do nietypowego i niespotykanego powszechnie odwrócenia roli prawa prywatnego i publicznego.

Zastrzeżenia budzą również uregulowania RODO dotyczące rozmiaru zagrożenia karami pieniężnymi. Nie tylko nie został on powiązany ze stopniem naruszenia interesu publicznego ${ }^{44}$, ale również sama rozpiętość oraz wysokość kar pieniężnych wywołuje wątpliwości z punktu widzenia zasady proporcjonalności, a w szczególności nadmiernej swobody decydowania o zastosowaniu sankcji. Trzeba mieć bowiem na względzie, że kary pieniężne mają charakter uznaniowy i podlegają merytorycznej kontroli sądu tylko w takim zakresie, w jakim ich wysokość rażąco odbiega od kwoty kary odpowiedniej za dane naruszenie ${ }^{45}$. Według art. 83 ust. 4-6 RODO, w zależności od rodzaju naruszenia kary pieniężne mogą zostać orzeczone do $10 \mathrm{mln}$ lub do $20 \mathrm{mln}$ euro, a w przypadku przedsiębiorstwa w wysokości do $2 \%$ lub do $4 \%$ jego całkowitego rocznego światowego obrotu z poprzedniego roku obrotowego, przy czym w każdym razie ostatecznie do kwoty wyższej. Takie rozwiązanie oznacza de facto brak górnej granicy zagrożenia sankcją ${ }^{46}$, w efekcie czego nie ma stałego ani pewnego punktu odniesienia w zakresie przyjęcia jednolitej miary stosowania kryteriów indywidualnego wymiary kary, o których mowa w art. 83 ust. 2 RODO. Może więc prowadzić do nierównego traktowania podmiotów dopuszczających się w tych samych okolicznościach faktycznych jednakowych naruszeń, co jest nie do pogodzenia z konstytucyjną zasadą równego traktowania (art. 32 ust. 1 konstytucji). Jest też sprzeczne z zasadą równości wobec prawa oraz z innymi

${ }^{43}$ Confer A. Kłoczko, Zasada proporcjonalności przy wymierzaniu kar pieniężnych za naruszenie przepisów prawa konkurencji. Analiza metody obliczania wysokości kar pieniężnych nakładanych na przedsiębiorstwa na przykladzie Unii Europejskiej, Turcji oraz Polski, „Internetowy Kwartalnik Antymonopolowy i Regulacyjny" 2016, nr 1, s. 10 i n.

44 Na marginesie należy wskazać, że w kontekście przepisów o ochronie konkurencji takie powiązanie zostało wyraźnie zaakcentowane, funkcjonuje i nie budzi zasadniczych wątpliwości. Vide np. D. Miąsik, Nakładanie kar pieniężnych — konieczność uwzględnienia przy nakładaniu i wymierzaniu kary pieniężnej stopnia naruszenia interesu publicznego, o którym mowa w art. 1 uokik, „Internetowy Kwartalnik Antymonopolowy i Regulacyjny" 2012, nr 4, s. 117 i n.

45 Vide np. wyrok SA z 17 maja 2012 r., sygn. akt VI ACa 31/12 wraz omówieniem D. Miąsik, op. cit.

46 Dążenie do zapobiegania możliwości budżetowania kar pieniężnych nie powinno usprawiedliwiać bezgranicznego zagrożenia karą, zwłaszcza że ma ona charakter uzupełniający względem sankcji cywilnych i karnych. 
wartościami wyrażonymi w KPP (art. 20 wraz z preambułą). Warto także dodać, że określony pułap wielkości obrotów stanowiący jeden z wyznaczników maksymalnej wysokości kary pieniężnej, choć jest wartością indywidualizującą, to jednak zawsze zmienną, która może nie pozostawać w jakimkolwiek związku przyczynowym ani z wyrządzoną szkodą, ani z korzyściami uzyskanymi z naruszenia przepisów RODO albo też w ogóle może nie wiązać się z żadnym innym efektem naruszenia tych przepisów. O nadmierności zagrożenia karą pieniężną świadczy także fakt, że w sytuacji, w której przedsiębiorstwo nie osiągnęło w danym roku obrotu, w RODO nie wskazano innego okresu jego zliczania, lecz maksymalną wysokość kary określono w sposób zryczałtowany kwotą do $10 \mathrm{mln}$ bądź do $20 \mathrm{mln}$ euro. Mimo zróżnicowania górnej granicy sankcji w zależności od rodzaju naruszenia oraz mimo określenia kryteriów miarkowania kar pieniężnych ich konstrukcja oraz wysokość również w wielu innych przypadkach nie zapewnia wymaganej adekwatności ${ }^{47}$. Tytułem przykładu kara pieniężna przewidziana w art. 83 ust. 5 RODO może zostać orzeczona $w$ razie naruszenia podstawowych zasad przetwarzania danych osobowych, o których mowa w art. 5, 6, 7 i 9 RODO, a zatem również w każdej sytuacji niezgodnego z prawem przetwarzania danych czy choćby tylko dokonywania operacji na danych osobowych w zakresie wykraczającym poza ich niezbędny cel.

Biorąc ponadto pod uwagę bardzo dużą liczbę różnych powinności oraz ich możliwych naruszeń, a także dopuszczalność kumulacji kar pieniężnych za niepowiązane ze sobą operacje przetwarzania danych osobowych, dotkliwość zagrożenia sankcjami karno-administracyjnymi wydaje się nadmierna w stosunku do wielu stypizowanych naruszeń, a przede wszystkim nieprzewidywalna. Przy niedomkniętej górnej granicy oraz bardzo dużej rozpiętości kar pieniężnych organy wymierzające ten rodzaj sankcji mają zbyt dużą swobodę orzekania ${ }^{48}$. W praktyce może ona prowadzić nie tylko do nierównego traktowania podmiotów, ale również do rozstrzygnięć niesprawiedliwych, a nawet skazujących na upadłość. Wskazane ryzyka zwiększa ponadto duża nieprecyzyjność przepisów nakładających poszczególne obowiązki sankcjonowane karami pieniężnymi przewidzianymi w RODO oraz w znacznej mierze ich ocenny charakter.

\section{WĄTPLIWOŚCI WOBEC ZNACZĄCO ODMIENNEGO TRAKTOWANIA PODMIOTÓW PUBLICZNYCH}

Istotny problemem natury konstytucyjnej stanowią ponadto kary pieniężne adresowane do podmiotów publicznych. Ich wysokość jest bowiem 100 razy lub 1000 razy,

${ }^{47}$ Według reguł przewidzianych w art. 83 RODO kary pieniężne mogą być nakładane bez związku ze szkodą, odniesionymi korzyściami, winą sprawcy, świadomością naruszenia, jego skali oraz stopnia społecznej szkodliwości. Wymienione okoliczności mogą natomiast wpływać na indywidualny wymiar kary pieniężnej.

${ }^{48} \mathrm{Na}$ gruncie prawa konkurencji w orzecznictwie sformułowano generalną tezę, że nie można uznać za nieproporcjonalną karę $\mathrm{w}$ wysokości dopuszczalnej krotności osiągniętych korzyści z naruszenia (vide wyrok SN z 13 czerwca 2017 r, sygn. akt III SK 43/16, Lex nr 2372552). A contrario można by więc przyjąć, że jeżeli nie osiągnięto żadnych korzyści z naruszenia i nie doszło do naruszenia interesu publicznego lub stopień jego naruszenia jest nieznaczny, kara nie powinna zostać nałożona. Sama forma winy czy fakt wyrządzenia szkody nie mogą decydować o zastosowaniu tej sankcji, chyba że chodzi o dużą skalę naruszenia oraz o szkodę dużych rozmiarów. 
a w niektórych przypadkach nawet 200 razy lub 2000 razy niższa od kar, którymi zagrożone są pozostałe podmioty. Wprawdzie bez uszczerbku w zakresie uprawnień organów nadzorczych, o których mowa w art. 58 ust. 2 RODO, państwa członkowskie mogą określić, czy i w jakim zakresie administracyjne kary pieniężne będzie można nakładać na organy i podmioty publiczne (art. 83 ust. 7 RODO), niemniej jednak nie może to oznaczać zupełnej dowolności zastosowanego rozwiązania. Tymczasem zgodnie $\mathrm{z}$ art. 102 ust. 1 i 2 u.o.d.o. na jednostki sektora finansów publicznych, o których mowa w 9 pkt 1-12 i pkt 14 ustawy o finansach publicznych [dalej: u.f.p.] ${ }^{49}$, instytuty badawcze oraz Narodowy Bank Polski, organ nadzorczy może - na zasadach przewidzianych w RODO — nałożyć karę pieniężną w wysokości do 100 tys. zł, a na jednostki sektora finansów publicznych, o których mowa w 9 pkt 13 u.f.p., karę w wysokości do 10 tys. zł. W związku z takim ukształtowaniem kar pieniężnych przez polskiego ustawodawcę powstaje więc pytanie, czy jest ono zgodne z zasadą równości wobec prawa, która jest zagwarantowana zarówno w konstytucji RP, jak i w prawie unijnym (art. 32 ust. 1 konstytucji oraz art. $20 \mathrm{KPP})$.

Wydaje się, że nie ma jakichkolwiek istotnych powodów, aby z publicznym statusem podmiotów naruszających przepisy RODO wiązać swoiste uprzywilejowanie w zakresie dolegliwości karania za jednakowe naruszenia. Cechą relewantną dla ustalenia adresatów danej sankcji jest dokonanie naruszenia określonych przepisów, a nie ich status formalny, który ma decydujące znaczenie jedynie w kwestii realizacji wobec nich kompetencji zgodnie z krajowym prawodawstwem. Podmioty publiczne powinny dawać dobry przykład, jeśli chodzi o przestrzeganie przepisów o ochronie danych osobowych, a nie być szczególnie usprawiedliwiane w przypadku ich naruszania. Jest zrozumiałe, że w przypadku tych podmiotów górna granica kary pieniężnej nie może wynikać z kryterium wielkości ich obrotu, jednocześnie nie ma jednak obiektywnego wytłumaczenia dla tak znacznego obniżenia jej wysokości. Zagrożenie istotnie mniejszą karą pieniężną prowadzi do jej całkowicie innego indywidualnego wymiarowania, a w konsekwencji do naruszenia konstytucyjnej gwarancji równości wobec prawa.

\section{WNIOSKI}

Biorąc pod uwagę wskazane wątpliwości dotyczące oceny konstytucyjności przepisów o ochronie danych osobowych, podjęte próby ich wyjaśnienia oraz stwierdzone uchybienia, należy zaapelować zarówno do unijnego, jak i krajowego prawodawcy o rozważenie zmian obowiązujących przepisów, w szczególności w zakresie ich sankcjonowania. Nie można utożsamiać każdego naruszenia przepisów o ochronie danych osobowych z naruszeniem interesu publicznego, a także aprobować stosowania sankcji karno-administracyjnych i karnych oraz ich wymiaru w oderwaniu od faktu i stopnia naruszenia interesu publicznego. Uwaga prawodawcy powinna koncentrować się nie tyle na sankcjonowaniu każdego naruszenia przepisów o ochronie danych osobowych,

${ }^{49}$ Ustawa z dnia 27 sierpnia 2009 r. o finansach publicznych (tekst jedn. Dz.U. z 2017 r. poz. 2077, ze zm.). 
ile raczej na skutecznym przeciwdziałaniu i zwalczaniu za pomocą wymienionych kar oraz innych środków najbardziej niebezpiecznych praktyk związanych z przetwarzaniem danych osobowych. Wobec dynamicznego rozwoju nowoczesnych technologii i wywierania przez nią coraz większego wpływu na faktyczną realizację konstytucyjnych praw i wolności oraz praw podstawowych, władza publiczna w znacznie większym stopniu niż dotychczas powinna zadbać o bezpieczeństwo obrotu.

Współcześnie za szczególnie niewystarczające należy uznać poleganie jedynie na zgodzie beneficjentów technologii jako podstawie przetwarzania danych osobowych, zwłaszcza wobec obiektywnej niemożliwości poznania wszystkich istotnych ryzyk wystąpienia określonych skutków, jakie wiążą się z wyrażeniem takiej zgody oraz stosowaniem technologii. Nakładanie wciąż nowych obowiązków informacyjnych tylko w niewielkiej części w istocie $\mathrm{i} w$ dużej mierze jedynie pozornie może rozwiązać ten problem z uwagi na ryzyko niekompletności i nieaktualności informacji, a także ze względu na ograniczone zdolności poznawcze beneficjentów technologii, przekładające się na ocenę podjęcia świadomej i wolnej woli. Niezbędne wydają się efektywne i bardziej bezpośrednie działania skierowane na ochronę bezpieczeństwa obrotu. Trzeba przy tym pamiętać, że zapewnienie bezpieczeństwa obrotu należy do podstawowych obowiązków władzy publicznej. Niepokojące jest natomiast, że RODO zamiast skutecznie realizować tę powinność, stało się główną siłą napędową dystrybucji nowoczesnych technologii informacyjnych. Zamiast zapobiegać i zwalczać najniebezpieczniejsze nadużycia związane z przetwarzaniem danych osobowych, stało się narzędziem wypierania tradycyjnego obrotu na rzecz obrotu elektronicznego. Tymczasem wbrew tym efektom UE gwarantuje ochronę praw podstawowych i zrównoważony rozwój, a konstytucje krajów członkowskich szereg różnych praw i wolności, które nie mogą być realizowane w sposób bezkolizyjny z przyjętym w RODO kształtem ochrony danych osobowych. Model ochrony danych osobowych przewidziany w RODO wymaga niezbędnej korekty, ponieważ został on częściowo oparty na błędnych założeniach.

\section{BIBLIOGRAFIA}

Bainczyk M., Polski i niemiecki Trybunał Konstytucyjny wobec członkostwa państwa w Unii Europejskiej, „Prace Naukowe Wydziału Prawa, Administracji i Ekonomii Uniwersytetu Wrocławskiego" 2017, nr 94 (seria e-monografie).

Banaszak B., Zasada nadrzędności Konstytucji w polskim porządku prawnym, [w:] Zasada pierwszeństwa prawa Unii Europejskiej w praktyce działania organów władzy publicznej, red. M. Jabłoński, S. Jarosz-Żukowska, „Prace Naukowe Wydziału Prawa, Administracji i Ekonomii Uniwersytetu Wrocławskiego" 2015, nr 58 (seria e-monografie).

Barta J., Fajgielski P., Markiewicz R., Ochrona danych osobowych. Komentarz, Wolters Kluwer, Warszawa 2015.

Biernat S., Glosy do wyroku Trybunału Konstytucyjnego z 11.05.2005 r. (zgodność Traktatu akcesyjnego z Konstytucja RP), K 18, glosa nr 2, „Kwartalnik Prawa Publicznego 2005”, nr 5-4.

Górski M., komentarz do art. 84 RODO, [w:] Ogólne rozporządzenie o ochronie danych osobowych. Komentarz, red. M. Sakowska-Baryła, C.H. Beck, Warszawa 2018. 
Jabłoński M., Jarosz-Żukowska S., Kontrola konstytucyjności prawa pochodnego w trybie skargi konstytucyjnej i pytań prawnych, [w:] Zasada pierwszeństwa prawa Unii Europejskiej w praktyce działania organów władzy publicznej, red. M. Jabłoński, S. Jarosz-Żukowska, „Prace Naukowe Wydziału Prawa, Administracji i Ekonomii Uniwersytetu Wrocławskiego" 2015, nr 58 (seria e-monografie).

Kłoczko A., Zasada proporcjonalności przy wymierzaniu kar pieniężnych za naruszenie przepisów prawa konkurencji. Analiza metody obliczania wysokości kar pieniężnych nakładanych na przedsiębiorstwa na przyktadzie Unii Europejskiej, Turcji oraz Polski, „Internetowy Kwartalnik Antymonopolowy i Regulacyjny" 2016, nr 1.

Kozik P., Zakres swobody regulacyjnej państw członkowskich przy wdrażaniu ogólnego rozporządzenia o ochronie danych osobowych do prawa krajowego, „Europejski Przegląd Sądowy” 2017, nr 5.

Lijowska M., Koncepcja ogólnego prawa osobistości w niemieckim i polskim prawie cywilnym, „Kwartalnik Prawa Prywatnego” 2001, z. 4.

Litwiński P., Barta P., Kawecki M., komentarz do art. 6 i 84 RODO, [w:] Rozporzadzenie UE $w$ sprawie ochrony osób fizycznych $w$ zwiazku z przetwarzaniem danych osobowych $i$ swobodnym przepływie takich danych. Komentarz, red. P. Litwiński, C.H. Beck, Warszawa 2018.

Miąsik D., Nakładanie kar pieniężnych - konieczność uwzględnienia przy nakładaniu $i$ wymierzaniu kary pieniężnej stopnia naruszenia interesu publicznego, o którym mowa $w$ art. 1 uokik, „Internetowy Kwartalnik Antymonopolowy i Regulacyjny” 2012, nr 4.

Nerka A., Sakowska-Baryła M., komentarz do art. 6 RODO, [w:] Ogólne rozporzadzenie o ochronie danych osobowych. Komentarz, red. M. Sakowska-Baryła, C.H. Beck, Warszawa 2018.

Relacje między prawem konstytucyjnym a prawem unijnym $w$ orzecznictwie sąów konstytucyjnych państw Unii Europejskiej, red. K. Zaradkiewicz, Wydawnictwo Trybunału Konstytucyjnego, Warszawa 2011.

Sibiga G., Dopuszczalny zakres polskich przepisów o ochronie danych osobowych po rozpoczęciu obowiqzywania ogólnego rozporzadzenia o ochronie danych - wybrane zagadnienia, „Monitor Prawniczy” 2016, nr 20 (dodatek).

Tuleja P., Stosowanie Konstytucji RP w świetle zasady jej nadrzędności (wybrane problemy), Zakamycze, Kraków 2003.

Wójtowicz K., Sądy konstytucyjne wobec prawa Unii Europejskiej, „Monografie Konstytucyjne” 2012, nr 3 . 